\title{
$\begin{array}{lllllllllllllllll}\mathbf{R} & \mathbf{O} & \mathbf{Z} & \mathbf{P} & \mathbf{R} & \mathbf{A} & \mathbf{W} & \mathbf{Y} & \text { I } & \text { A } & \mathbf{R} & \mathbf{T} & \mathbf{Y} & \mathbf{K} & \mathbf{U} & \mathbf{L} & \mathbf{Y}\end{array}$
}

Prawo Kanoniczne

62(2019) nr 1

DOI:10.21697/pk.2018.62.1.01

O. TOMASZ GAŁKOWSKI C.P.

Wydział Prawa Kanonicznego

Uniwersytetu Kardynała Stefana Wyszyńskiego w Warszawie

ORCID: 0000-0001-9166-9516

\section{PRAWO KANONICZNE CZY KOŚCIELNE?}

Treść: Wstęp. - 1. Prawo w Kościele pierwotnym. - 2. Słowne formy wyrażania prawa Kościoła. - 3. Prawo Kościoła.

\section{Wstęp}

Pytanie postawione w tytule niniejszego przedłożenia nie zrodziło się u jego autora. Czytelnikowi należy się zatem wyjaśnienie, dlaczego taki tytuł się pojawił. Chodzi o sposób odniesienia do prawa Kościoła $^{1}$ odpowiednich określeń, które pojawiały się w historii i które były powszechnie akceptowane. Ich różnorodność jest świadectwem bogactwa prawa Kościoła, które przyjmowało nazwy w zależności od wielu czynników, sytuacji i potrzeb, ale w przeważającej mierze celem wskazania, że jest to prawo własne wspólnoty kościelnej, niezależne od wpływów prawa istniejącego poza Kościołem.

Pytanie zawarte w tytule nie jest wyrazem wątpliwości dotyczącej możliwości odniesienia obydwu określeń do zjawiska prawnego w Kościele. Nie z tego też powodu się pojawiło. Uzasadnieniem pytania są tezy, które pojawiały się w kręgu polskich kanonistów podczas spotkań, w których miałem okazję uczestniczyć. Otóż w ich trakcie

\footnotetext{
${ }^{1}$ Niezależnie od zastosowanego do prawa istniejącego w Kościele określenia, dotyczy ono prawa Kościoła. Tym określeniem wskazuje się, że mamy do czynienia $\mathrm{z}$ prawem, które jest prawem własnym Kościoła w znaczeniu, iż wynika z jego natury, z tego czym Kościół jest w swojej istocie jako znak i narzędzie zbawienia.
} 
padały stwierdzenia, które wyraźnie stawiały w opozycji dwa powyższe określenia. Prawo kanoniczne, zdaniem wypowiadających się kanonistów, jest prawem zawartym w obu kodeksach prawa Kościoła katolickiego (KPK, KKKW). Określenie dotyczy zatem postanowień normatywnych zawartych w kodeksach. Prawo kanoniczne zostało zredukowane do prawa kodeksowego, co nie odpowiada historycznemu i tradycyjnemu odniesieniu tego pojęcia do prawa Kościoła zanim pojawiły się w nim kodeksy. Zgodnie z takim przekonaniem należałoby, przyjmując stanowisko metodologicznych purystów, nie stosować pojęcia prawa kanonicznego do prawa Kościoła przed wejściem w życie kodeksu w 1917 r. Czy jednak określenie prawo kanoniczne, które pojawiło się w nazwie prawotwórczego dokumentu nie było wcześniej stosowane? Czy zastosowanie w nazwie kodeksu ograniczyło jego znaczenie jedynie do prawa, które jest wynikiem działalności prawodawczej wyrażonej w nowej formie kodeksowej? Czy ustawodawca miał na myśli lub nawet chciał doprecyzować w ten sposób pojęciowy desygnat? Odpowiedzi twierdzące powinny skutkować konsekwentnym odniesieniem pojęcia prawa kanonicznego jedynie do prawa kodeksowego i wykluczałyby zatem możliwość stosowania tego pojęcia ogólnie do prawa Kościoła. Można dalej mnożyć pytania dotyczące prawa, które w swych pozytywnych sformułowaniach konkretnie ujmuje w historycznym momencie zobowiązujące wymagania wynikające z wiary. Należałoby mu odmówić możliwości odniesienia do niego pojęcia prawa kanonicznego. I taka była opinia tych kanonistów, którzy dokonywali rozróżnienia na prawo kanoniczne i kościelne. Do prawa Kościoła zawartego w pozakodeksowych aktach ustawodawczych stosowali określenie prawo kościelne.

Powyższe rozróżnienie uważam za niesłuszne. Nie jest to powodowane jedynie racjami odwołującymi się do kanonistycznej tradycji, w której na określenie zjawiska prawnego w Kościele posługiwano się wieloma pojęciami. Stosowane określenia były wyrazem świadomości istnienia własnego porządku prawnego wspólnoty wierzących. Rodziły się pod wpływem działalności zmierzającej do ukazania prawnego wymiaru Kościoła i jego wiary. Jako takie były elementem wtórnym w stosunku do pierwotnego zjawiska prawnego, które 
wyrażano w odpowiednich i zrozumiałych sformułowaniach. Pojawiające się w dyskusji rozróżnienie na prawo kościelne i kanoniczne, tak jak dane mi to było zrozumieć z wyjaśnień autorów powyższego stwierdzenia, nie dotyczy jednak zjawiska prawnego, lecz działalności ustawodawczej dokonywanej w formie kodeksowej czy pozakodeksowej. Efektem działalności ustawodawczej jest nie tyle kodeks, lecz ustawa. Kodeks jest formą ustawy i ze względu na tę formę dokonuje się rozróżnienia na ustawę kodeksową czy ustawy okołokodeksowe.

Odmienne odniesienie określeń prawo kanoniczne i prawo kościelne do prawa kodeksowego lub pozakodeksowego skutkuje wykluczeniem możliwości stosowania tychże sformułowań w stosunku do prawa zwyczajowego. Czy prawo zwyczajowe w Kościele to prawo kanoniczne czy kościelne? Zgodnie ze stanowiskiem odróżniającym prawo kościelne od kanonicznego, które odnosi się do konkretnych form działalności ustawodawczej, nie można by stosować do zwyczajów istniejących w Kościele jako faktów prawnych ani jednego, ani drugiego określenia. Inną ewentualną możliwością karkołomnego procesu myślowego mogłaby być próba określenia prawa zwyczajowego jako kanonicznego, gdyż ustawodawca w kanonach kodeksu reguluje możliwość uznania faktu zwyczajowego jako faktu prawnego. Zwyczaj byłby uznawany za prawo kanoniczne. Z drugiej jednak strony to nie kanony kodeksu, ani decyzja przełożonych są jedynym źródłem formalnym prawa zwyczajowego. Pierwszorzędnym, aczkolwiek nie bezpośrednim, formalnym źródłem prawa zwyczajowego, obok samego faktu, jest zamiar zobowiązania się wspólnoty wiernych do zachowań zgodnych z treścią zwyczaju, czyli zamiar wspólnoty wprowadzenia zwyczaju w życie. W tym znaczeniu należałoby określić zwyczaj kościelny mianem prawa kościelnego. Czy jednak terminologiczne rozróżnienie przyczynia się tym razem do precyzacji i zrozumienia zjawiska prawnego wzbudzonego faktem zwyczajowym?

W oparciu o kryterium obecności przepisów prawnych w kodeksach lub poza nimi dodatkowo w dyskusjach pojawiło się przeciwstawienie prawa kanonicznego prawu liturgicznemu, gdyż to drugie zazwyczaj zawarte jest w księgach liturgicznych. Zgodnie z takim 
sposobem ujmowania zagadnienia prawo liturgiczne powinno być również prawem kościelnym. Jednak według autorów tego pomysłu prawo liturgiczne jest czymś odrębnym od prawa kościelnego. Samorzutnie pojawia się pytanie odnośnie do przepisów dotyczących liturgii, które zawarte są w kodeksach. Powinny być częścią prawa kanonicznego. W konsekwencji prawo regulujące liturgię Kościoła byłoby raz prawem kanonicznym, innym razem prawem liturgicznym albo prawem kościelnym. Jeśli zatem prawo liturgiczne jest częścią prawa kanonicznego i jednocześnie prawa kościelnego, regulując jedną liturgię Kościoła, to nie dostrzegam podstawy, by odnosić do niego dwa koncepcyjne określenia wyróżnione w oparciu o miejsce zawarcia regulacji normatywnych. Historyczna postać kształtowania się prawa Kościoła wskazuje, że to liturgia była pierwotnym miejscem tego procesu, gdyż dyscyplina pierwszych wspólnot chrześcijańskich rozwijała się wokół sprawowanego w dzień Pański paschalnego misterium Chrystusa².

Przedstawiony powyżej sposób mówienia o prawie Kościoła i odróżnianie prawa kanonicznego od kościelnego w oparciu o kryterium, jakim są miejsce i sposób istnienia kościelnych przepisów wskazują także na preferencje naukowe kanonistów. Pozwalają na określenie ich orientacji w uprawianiu kanonistyki, a w niej ujmowania prawa Kościoła. Przedstawione poglądy zdradzają orientację kanoniczno-dogmatyczną, zgodnie z którą prawo Kościoła jest konsekwencją widzialnego aspektu Kościoła lub prawno-kulturową, według której prawo Kościoła uzasadnia się kategorią podstawowego porządku prawnego, którego Kościół jest jednym z przykładów ${ }^{3}$.

Uważam, że rozróżnienie na prawo kanoniczne i prawo kościelne nie ma podstaw. Oba sformułowania dotyczą tej samej rzeczywistości prawa Kościoła, wskazując na charakterystyczne jego cechy jako zjawiska na pierwszym miejscu kościelnego. Prawo Kościoła jako

\footnotetext{
${ }^{2}$ Ł. Korporowicz, Prawo liturgiczne Kościoła łacińskiego a Kodeks prawa kanonicznego z 1983 roku, Studia Prawno-Ekonomiczne 91 (2014) 1, s. 26.

${ }^{3}$ R. SobAŃski, Nauki podstawowe prawa kanonicznego. T. 2. Teologia prawa kościelnego, Warszawa 2001, s. 25-26.
} 
rzeczywistość kościelna jest rzeczywistością prawną. Argumenty, które wskazują na ten sam desygnat pojęcia prawa kanonicznego i kościelnego przedstawię w oparciu o doświadczenie prawa w Kościele pierwotnym, świadomość prawa u pierwszych chrześcijan oraz sposób wyrażania własnego prawa.

\section{Prawo w Kościele pierwotnym}

Ważniejsza od nazewnictwa jest kwestia związana $\mathrm{z}$ istnieniem własnego prawa wspólnoty chrześcijańskiej i przekonania co do charakteru owego zjawiska jako faktu prawnego. Nazwa pojęciowa dotyczy zjawiska wyodrębnionego spośród innych i wskazuje na jego cechy specyficzne pozwalające na odróżnienie go od, czasem podobnych, ale różnych zjawisk.

Opracowania z zakresu historii prawa kościelnego, historii źródeł i instytucji kanonicznych czy też historii nauki prawa kanonicznego opisują i analizują zjawisko prawa kościelnego, wskazują na normy dyscyplinarne organizujące życie kościelnej wspólnoty zapisane czy to na kartach Biblii czy u Ojców Apostolskich i Ojców Kościoła. Z tego też powodu ich pisma można i należy traktować jako źródła prawa pierwotnego Kościoła o ile ujmowane są jako świadectwa istniejących w tym okresie regulacji prawnych. Powszechność dostępu do nich czy też podstawowa wiedza z zakresu pierwotnego piśmiennictwa chrześcijańskiego zwalnia mnie od przywoływania świadectw regulacji prawnych w nich zawartych na potwierdzenie tezy o istnieniu niezależnych od zewnętrznych stanowień norm regulujących życie pierwszych chrześcijan. Moje uwagi mają charakter bardziej polemiczny i dyskusyjny niż naukowego opracowania. Odwołują się zatem do wiedzy, jeśli nie posiadanej, to z pewnością powszechnie dostępnej. Bardziej znaczącym wydaje mi się przywołanie świadectw spoza świata chrześcijańskiego wskazujących na istnienie we wspólnotach chrześcijańskich własnego i niezależnego prawa oraz sformułowanie odpowiednich wniosków.

Dla Rzymian, których kultura prawna osiągała w tym czasie apogeum, tworzone przez chrześcijan normy postępowania określane były mianem leges, a rzymskie sformułowanie lex christiana, chociaż 
nie w pełni odpowiadało chrześcijańskiej treści, nie było czymś nieznanym w chrześcijańskim świecie ${ }^{4}$. Cesarz Galeriusz w edykcie ogłaszającym koniec prześladowań (311 r.) napisał znaczące dla ówczesnej sytuacji prawa chrześcijan słowa: „sed pro arbitrio suo atque ut isdem erat libitum, ita sibimet leges facerent quas observarent"5. Galeriusz uzasadnia prześladowanie chrześcijan nie tyle tym, że stworzyli sobie jakiś nowy kult religijny, lecz tym, że żyli w cesarstwie rzymskim w oparciu o tworzone przez siebie prawa. Cesarstwo rzymskie z zasady okazywało się tolerancyjne w stosunku do kultów religijnych, o ile nie naruszały porządku publicznego, nie zagrażały państwowym interesom, a ich wyznawcy akceptowali kult cesarza ${ }^{6}$. Ostatni wymóg pokojowego funkcjonowania chrześcijan w cesarstwie rzymskim nie mógł być przez nich spełniony. Ale o tym Galeriusz w Edykcie tolerancyjnym nie wspomina. Jeśli wspomina jedynie o tworzonych przez chrześcijan prawach, których dodatkowo przestrzegają pomimo prześladowań ze strony rzymskiego cesarstwa, to można w znacznej mierze przypuszczać, że treść tych praw była dla Rzymian powodem oburzenia czy skandalu. Faktem, który nie był przez nich akceptowany, było prawo, które nie pochodziło od cesarstwa, a które w cesarstwie istniało i było przestrzegane.

Galeriusz pisze o zachowaniu chrześcijan zgodnie z ich prawami, używając sformułowania charakterystycznego dla prawa rzymskiego leges. Trudno jest określić precyzyjnie i jednoznacznie, co Galeriusz miał na myśli, używając takiego sformułowania. W okresie cesarstwa termin leges jako pojęcie ogólne stosowany był przez prawników klasycznych oraz w ustawodawstwie cesarskim na oznaczenie: edicta, rescripta, decreta, mandatum ${ }^{7}$. Leges odnosiły się zatem do prawa stanowionego przez tych, którzy mieli do tego upoważnienie.

\footnotetext{
${ }^{4}$ Tenże, Prawo w prawie kościelnym, Prawo Kanoniczne 36 (1993) 1-2, s. 13.

${ }^{5}$ Lactantius, De Mortibus Persecutorum, https://www.thelatinlibrary.com/lactantius/demort.shtml, nr 34 [dostęp: 10.01.2019].

${ }^{6}$ A. Dembiński, Kościót i prawo rzymskie, Lublin 2008, s. 10.

${ }^{7}$ J. Kamiński, Leges, w: Prawo rzymskie. Słownik encyklopedyczny, red. W. Wołodkiewicz, Warszawa 1986, s. 88.
} 
Odniesienie tego sformułowania do chrześcijaństwa wskazuje, że stanowione przez chrześcijan reguły postępowania były traktowane jako równoznaczne prawom rzymskim i dlatego zwalczane.

Łagodniejszym tonem o znaczeniu prawa dla chrześcijan i jego pojmowaniu przez Rzymian wypowiada się D. Rops. Analizując przyczyny wydania Edyktu tolerancyjnego przez Konstantyna w 313 r., wskazuje, że argumentacja odwołująca się do prawa chrześcijan była dla cesarzy sposobem pozwalającym na uznanie Boga chrześcijan za silniejszego od rzymskich bogów, skoro przyczynił się do odniesionego przez Konstantyna zwycięstwa nad Maksencjuszem przy Moście Mulwijskim. Tym samym cesarz mógł wytłumaczyć dotychczasowe prześladowania chrześcijan nie tyle ich wiarą w innego Boga, lecz tworzonymi przez nich prawami, co było niedopuszczalne i nie do przyjęcia. Z drugiej jednak strony pozwoliło na przyjęcie przez prosty lud tezy i wytworzenie w nim przekonania, że „zwycięstwo Chrystusa zapisane było w tajemniczych kartach losu"

Zarówno Galeriusz, jak i Konstantyn potwierdzają fakt istnienia u chrześcijan form regulacji ich życia, które nazywane są przez Rzymian leges. Nie wydaje się, by mogli stosować tę nazwę, gdyby faktycznie nie istniała rzeczywistość nazywana przez nich w ten jednoznacznie określony sposób. Potwierdza to, że chrześcijanie w okresie prześladowań żyli zgodnie ze swoimi prawami stanowionymi niezależnie od władzy rzymskiej. Na tę autonomię zwraca uwagę św. Hieronim, pisząc w Liście do Oceana: „Aliae sunt leges Caesarum, aliae Christi: aliud Papinianus, aliud Paulus noster praecipit"9.

Chrześcijanie tworzyli własne prawo niezależne od prawa rzymskiego ${ }^{10}$. W opinii niektórych Ojców Kościoła (np. Augustyn) normy

${ }^{8}$ D. Rops, Kościół pierwszych wieków, Warszawa 2013, s. 356. Pisze Rops: „Zamiast przypisywać nieszczęścia spadające na państwo bezbożności chrześcijan, jak to czyniono dawniej, należało raczej szukać ich prawdziwych przyczyn w długotrwałym odrzucaniu przez Rzym nowego prawa" (tamże).

${ }^{9}$ Ad Oceanum, w: J. P. Migne, Patrologiae Latinae Cursus Completus, 22, 691.

${ }^{10}$ Pozabiblijne świadectwa tego prawa znajdujemy w: Didache z końca I w., które określane jest mianem corpus iuris canonici Kościoła pierwotnego, Tradycji apostolskiej (ok. 218 r.), Didaskaliach, czyli nauce dwunastu apostołów (początek III w.). 
postępowania wyrażone w zbiorach pseudoapostolskich nie miały charakteru normy prawnej, lecz jedynie moralnego zobowiązania w sumieniu. Ich moc zobowiązująca uzależniona była od autorytetu ich autora. Odnosiły się bowiem do zasad postępowania w perspektywie zbawienia. Nabierały charakteru prawnego o ile zostały włączone do późniejszych dekretałów czy postanowień synodalnych ${ }^{11}$.

Według rzymskich kryteriów normy te jednak były prawem, zwłaszcza wtedy, gdy występowały przeciwko postanowieniom prawa rzymskiego i skutkowały ich przestrzeganiem. Określenie tego prawa mianem leges wskazywało również na przynależność owych leges do porządku prawnego (ius) w odróżnieniu od uznawanego w cesarstwie rzymskim porządku boskiego ( $f a s)$, sfery działania ludzkiego dozwolonej i chronionej przez religię. W rozumieniu rzymskim prawo chrześcijan nie posiadało zatem transcendentalnego odniesienia do bóstwa. Chrześcijanie takiego rozumienia prawa nie mogli zaakceptować. Ich prawo, zasady życia (regulae fidei, morum, disciplinae) nie były ludzkiego pochodzenia, lecz swoje źródło miały w wyznawanej wierze. Wspólnota wiary była bowiem znakiem zbawczego działania Boga i miała za zadanie takie działanie odzwierciedlać i urzeczywistniać poprzez odniesienie do Boga i bliźniego. Więzią zobowiązującej jedności pomiędzy nimi nie były ludzkie stanowienia, lecz obecny we wspólnocie poprzez swojego Ducha sam Chrystus. Dlatego wiara chrześcijańska miała charakter społeczny. Normy regulujące życie chrześcijan miały ją odzwierciedlać i urzeczywistniać. Były to normy, których źródłem było obdarowanie wiarą. Różnica w pojmowaniu zobowiązujących form postępowania pomiędzy chrześcijanami a światem zewnętrznym prowadziła do jej ukazania

Zbiory pseudoapostolskie, cieszące się dużym uznaniem zwłaszcza na Wschodzie, uznawane są w literaturze za „zalążki” prawa kanonicznego, A. Dembiński, Kościót i prawo rzymskie, s. 24-26. J. Gaudemet twierdzi, że powszechnie uznaje się za pierwszy tekst prawny Kościoła Pierwszy List Klemensa Rzymskiego do Kościoła w Koryncie. J. Gaudemet, Storia del diritto canonico. Ecclesia et Civitas, Cinisello Balsamo 1998, s. 48. Autor pisze też o Tradycji apostolskiej jako dokumencie, który zawiera najstarszy przekaz kościelnego porządku prawnego (tamże, s. 50-51).

${ }^{11} \mathrm{~J}$. Gaudemet, Storia del diritto canonico, s. 61-62. 
przez specyficzne słownictwo, które jednak nie negowało do końca możliwości aplikacji tego, które istniało w świecie prawa. Dotyczyło to samego prawa, które posiadało swoje znaczenie w historii Bożego Objawienia. W tej perspektywie, nie zaś w odniesieniu do prawa rzymskiego, pojęcie prawa posiada znaczenie dla chrześcijan. Nie tyle zatem treść i przedmiot prawa, co treść samego pojęcia prawa stanowi o prawie Kościoła. Z tego też powodu prawo Kościoła pierwotnego wykraczało poza obiegowe pojęcia prawa. Szerszy zakres pojęciowy prawa, z którym utożsamiali się chrześcijanie, pozwolił również na przyjęcie wszelkich możliwych form prawnych pozwalających na wyrażenie ich własnego prawa ${ }^{12}$.

\section{Słowne formy wyrażania prawa Kościoła}

Chrześcijanie kształtują swoje prawo według własnych kryteriów. Nie przyjmują formalnych kryteriów rzymskich, które decydują o charakterze prawnym rozwiązań normatywnych. Czują się wolni od rzymskich zasad stosowania prawa. Nie wynika to jedynie z treści wiary, którą żyją. Wiedzą bowiem, że ich wiara przekracza granice państw i dotyczy każdego wiernego bez względu na istniejące podziały odróżniające obywateli od innych poddanych państwa. Warunkiem zobowiązującym do przestrzegania wymagań wiary jest jedynie chrzest, który przyjmują i który decyduje o przynależności do jednej wspólnoty kościelnej.

Chrześcijanie przekazują swoje zasady postępowania, wyznając i głosząc wiarę. Wiara przekazywana jest na sposób dogmatyczny i dyscyplinarny. Prawo chrześcijan staje się formą komunikacji wiary, sposobem ewangelizacji. Praktyką potwierdzają wyznawaną wiarę. Od momentu przyjęcia wiary wypełniają Chrystusowy nakaz, by iść i głosić Królestwo Boże. Poszukują jednocześnie najlepszych i w miarę jednoznacznych oraz wspólnych form życia, które świadczyłyby o chrześcijańskiej wspólnocie niezależnie od miejsca przebywania, tak by każdy mógł się zawsze odnaleźć pomiędzy braćmi, którzy wyznają tę samą wiarę. Formułowanie zasad chrześcijańskiego życia jest

${ }^{12}$ R. Sobański, Prawo w prawie kościelnym, s. 13. 
nierozłącznie związane z artykulacją wiary. Z tego powodu w ocenie zobowiązujących form życia chrześcijańskiego istotne jest kryterium rzeczowe, czyli zgodność życia z objawioną wolą Boga, który jest dla nich ostatecznym źródłem prawa ${ }^{13}$. W tym sensie prawo kościelne kształtowało się niezależnie od formalnych warunków decydujących o prawnym charakterze norm postępowania. Świadectwo takiego życia przekazują zbiory pseudoapostolskie, które zawierają praktyczne rady odnoszące się do zasad postępowania w życiu prywatnym i wspólnotowym, odpowiadające duchowi apostolskiej tradycji.

Prawo Kościoła kształtuje się w kontakcie ze światem i jego prawem. Chrześcijanie korzystają z niektórych osiągnięć rzymskiej jurysprudencji czy w szerszym zakresie z terminologii prawnej, którą wykorzystują w pismach teologicznych celem zdefiniowania relacji człowieka z Bogiem (pater i dominus) oraz pomiędzy wyznawcami Chrystusa

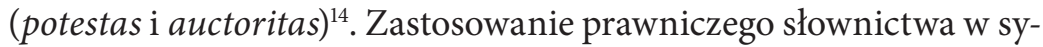
tuacjach odnoszących się do wiary i z niej wynikających wskazuje, że w niej samej należy szukać podstaw zobowiązujących chrześcijan do relacji prawnych. $Z$ drugiej strony daje wyraz przeświadczeniu, że aparat pojęciowy pochodzący ze świata prawa rzymskiego nadaje się do wyrażenia własnego doświadczenia wiary w sposób zrozumiały dla chrześcijan i pogan. Dzięki wspólnym pojęciom istnieje możliwość dokonywania porównań, ukazywania elementów wspólnych oraz różnic pomiędzy doświadczeniem prawnym wewnątrz i poza chrześcijaństwem. Kościół, dokonując symbiozy czy też dystansując się lub nawet odrzucając aparat pojęciowy, poszukuje form komunikacji adekwatnych do przekazywanych treści. Wykorzystuje zatem to, co sprawdzone i co może okazać się skuteczne. Aczkolwiek doświadczenie prawne nie jest zależne od pojęć, to jednak pojęcia wypełnione nową treścią mogą posłużyć do jego wyrażenia. W przypadku doświadczenia prawnego chrześcijan wykorzystanie aparatury pojęciowej polega nie tyle na jej przeniesieniu czy zapożyczeniu z powodu braku

\footnotetext{
${ }^{13}$ Tenże, Nauki podstawowe prawa kanonicznego. T. 2. Teologia prawa kościelnego, s. 43.

${ }^{14}$ A. Dembiński, Kościół i prawo rzymskie, s. 26-27.
} 
własnych terminów, ile na ich odniesieniu do nowego doświadczenia prawnego, które nadaje im własną treść.

O ile jednak chrześcijanie korzystali z terminologii istniejącej w pogańskim świecie prawa, o tyle trudniejszym zadaniem było korzystanie z określeń odnoszących się do samego zjawiska prawnego. Wynikało to z doświadczenia prawnego i prawa ludu Starego Testamentu, gdzie odnosiło się ono do zbawczego planu Boga wobec świata. Chrystus nie zmieniając ani jednej litery w tym prawie ukazał jego prawdziwy sens w odniesieniu do Boga, który jest Ojcem. Wypełnił je do końca i wskazał na możliwości życia zgodnie z nim, gdyż wiara przez miłość rodzi czyny zgodne z prawem. Wiara i miłość są środkami umożliwiającymi wypełnienie prawa. Dzięki nim chrześcijanin wypełnia swoje powinności wobec Boga i drugiego człowieka. Daje świadectwo wierze i spełnia swoje zobowiązania. Takie postępowanie czyni go sprawiedliwym przed Bogiem. Usprawiedliwienie przed Bogiem staje się nowym kryterium chrześcijańskiego prawa ${ }^{15}$. Z tego powodu świeckie rozumienie prawa nie mogło stać się punktem odniesienia dla rozumienia prawa chrześcijan. Prawo dla chrześcijan było nowym prawem, obowiązującym jedynie w ich wspólnocie, ze względu na koniecznoś realizacji nowej sprawiedliwości, której treść wyznaczona jest przez Bożą Miłość i jako taka ma być znakiem dla świata ${ }^{16}$. Usprawiedliwienie przed Bogiem i sprawiedliwość większa niż faryzeuszów i uczonych w Piśmie (Mt 5, 20) były podstawą wypełniania przez nich prawa i dostrzegania jego sensu. To Bóg jest dla chrześcijan „początkiem i kresem prawa” (Rz 10,4).

Obecność chrześcijan w świecie nie jest od samego początku nastawiona na tworzenie prawa. Ich zadaniem jest głoszenie Królestwa Bożego. Jeśli można mówić o stanowieniu prawa, traktując to stwierdzenie w sensie analogicznym, należy stwierdzić, że dokonuje się ono poprzez codzienne życie zgodne $z$ wyznawaną wiarą. Prawo jest odczytywane, wydobywane i przekazywane, a jako takie stanowione.

\footnotetext{
${ }^{15}$ R. SobAński, Nauki podstawowe prawa kanonicznego. T. 2. Teologia prawa kościelnego, s. 36-41.

${ }^{16}$ TAMŻE, s. 50.
} 
Chrześcijanie żyjąc w odpowiedni sposób wyrażają i przekazują zobowiązujące formy postępowania. Żyjąc wiarą, stanowią prawo. Poszukują jak najbardziej adekwatnych do wiary, słusznych a tym samym komunikatywnych sposobów życia.

Prawo Kościoła, zanim przybrało formalny kształt zrozumiały dla świata zewnętrznego, posiadało już swoją historię. Ale i liczebny wzrost chrześcijaństwa wymagał z czasem jednoznacznego i zrozumiałego określenia tego, w co chrześcijanie wierzą oraz tego, co z tej wiary wynika. Pojawia się instytucja synodów, podczas których biskupi prowincji kościelnej dyskutują i decydują o sprawach wiary, dyscypliny, obyczajów, jak również w sprawach lokalnych czy personalnych. Pierwszy Synod ekumeniczny w Nicei (325 r.) jest przykładem postanowień dotyczących tego, w co należy w Kościele wierzyć, co jest obowiązujące i co decyduje o przynależności do niego. Do wcześniejszej praktyki prawa przekazywanego dołączyła praktyka stanowienia prawa. Prawo w ten sposób stanowione nie było jednak wynikiem odgórnych decyzji, lecz akceptacją istniejącej i rozwijającej się praktyki życia chrześcijańskiego ${ }^{17}$.

Procesowi kształtowania się doświadczenia prawnego chrześcijan nie towarzyszy jednak określony sposób nazywania przez nich swoistej praktyki życia. Święty Paweł w Liście do Galatów $(6,16)$ pisze o nowych zasadach życia chrześcijańskiego, które wynikają z przyjęcia nowości Chrystusowego krzyża określając je mianem kanonu. Kanon, tłumaczony na język łaciński jako reguła, służy zatem Pawłowi do wyrażenia konkretnych wskazań życiowych. Użyty w tym kontekście odnosi się do nowości życia w Chrystusie i związanego z tym postępowania, które zjednuje wiernemu pokój i miłosierdzie.

Z określeniem doświadczenia prawnego chrześcijan mianem ius, zrozumiałym w świecie rzymskim, spotykamy się u Tertuliana. Przyjmuje się, że po raz pierwszy ten termin został zastosowany do Kościoła. Tertulian pisze o jedności wszystkich Kościołów, o której świadczą zachowywany w nich pokój, nazywanie siebie braćmi oraz więź gościnności. W odniesieniu do tych więzów stosuje określenie

\footnotetext{
${ }_{17}$ TenżE, Nauki podstawowe prawa kanonicznego. T. 1. Teoria prawa kanonicznego, Warszawa 2001, s. 26-27.
} 
prawo (ius), którego podstawą jest przekaz tej samej tajemnicy (nauki). Tertulian wskazuje na więzy istniejące pomiędzy wyznawcami Chrystusa dostrzegając ich zobowiązujący (prawny) charakter, którego źródło znajduje się w przekazie jednej wiary ${ }^{18}$.

Termin ius nie był jednak powszechnie stosowany na określenie doświadczenia prawnego w Kościele pierwotnym. Dopiero pod koniec IV w. zaczął być stosowany na oznaczenie prawa Kościoła określanego jako ius ecclesiasticum (prawo kościelne). Nie było to jedyne określenie. Występowały również takie, jak: prawo Boże (ius divinum) w przeciwieństwie do prawa cywilnego (ius humanum), gdyż wiele norm posiada swoje źródło w odniesieniu do Boga; prawo święte (ius sacrum) ze względu na świętość autora prawa, jego treść i cel; prawo papieskie (ius pontificium) w odróżnieniu od praw wydawanych przez władzę świecką (ius caesareum) i jako papieskie obowiązujące w całym Kościele; prawo kanoniczne (ius canonicum) ${ }^{19}$; prawo dekretałów (ius decretalium) na oznaczenie prawa papieskiego obowiązującego w całym Kościele i wydawanego w formie dekretałów.

Wracając do pytania postawionego w tytule, zwróćmy uwagę na znaczenie, jakie miały dwa występujące w nim określenia prawa Kościoła: ius ecclesisticum i ius canonicum. Pierwsze z nich uważane jest za pierwotne określenie prawa Kościoła. Pojawiło się w połowie IV w. Określenie to znajdujemy np. w liście papieża Syrycjusza do Himeriusza z 385 r., w którym zestawia obok siebie leges i iura ecclesiatica $^{20}$. Odwołanie się do prawa kościelnego przez papieża nie

\footnotetext{
18 Tertulian, De praescriptione haereticorum (20, 25-28). Tłum. pol. Preskrypcja przeciw heretykom, Kraków 2012: „Przez ten fakt, wszystkie kościoły są również pierwotne, i apostolskie, bo wszystkie stanowią jeden tylko Kościół. Tej jedności dowodzi również: łączność wszystkich w pokoju, nazywanie się wzajemnie braćmi, oraz przestrzeganie więzów gościnności. Tymi trzema prawami (quae iura) nie kieruje inna zasada, jak właśnie jedność tej samej nauki, przekazywanej tą samą tradycją (eiusdem sacramenti una traditio)".

${ }^{19}$ F. M. Cappello, Summa Iuris Canonici, vol. I, Romae 1961, s. 9-10.

${ }^{20}$ "quod et publicae leges et ecclesiastica jura condemnat ", Siricius, Epistula ad Eumerium Tarraconensem Episcopum, w: J. P. Migne, Patrologiae Latinae Cursus Completus, 84, 633.
} 
wskazuje jednak, by określenie to było początkowo stosowane na oznaczenie całości prawa obowiązującego w Kościele. Początkowo odnosiło się do obiektywnej normy, do której powinien zastosować się jej adresat ${ }^{21}$. Odpowiednikiem tego sformułowania było greckie

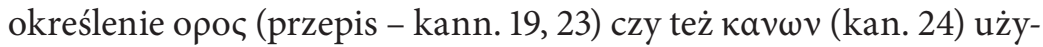
wane wcześniej w kanonach synodu w Ancyrze (314 r. $)^{22}$. Dopiero z biegiem czasu określenie zaczęło oznaczać całość reguł i wskazań dotyczących kościelnej dyscypliny ${ }^{23}$. Przyjęte jest w literaturze, że od XII w. stosuje się zarówno określenie prawo kanoniczne jak i prawo kościelne na oznaczenie całości praw obowiązujących w Kościele.

Nazwa prawo kanoniczne ma swoje źródło w sposobie wyrażania zobowiązujących norm postępowania, które wskazywano jako kanony, tłumaczone na język łaciński jako reguły, jak to mamy w liście św. Pawła do Galatów. Reguły postępowania nie były tworzone w oparciu o formalne kryteria reguł prawnych, gdyż chrześcijanie nie byli nastawieni na tworzenie prawa, lecz na głoszenie Królestwa Bożego i potwierdzanie jego obecności i oczekiwania w postępowaniu świadczącym o jego doświadczeniu. Wskazania określone mianem kanonów nie były jednak jedynie zachętami czy dobrymi radami, lecz wiążącymi regułami wskazującymi możliwość osiągnięcia tego, co nakazują poprzez postępowanie w nich wyznaczone. Kanony są podstawowymi regułami dyscyplinarnymi obowiązującymi w Kościele, wskazaniami kierującymi życiem wspólnoty kościelnej. W tym znaczeniu występują na synodach z początku IV w. w Ancyrze (314 r.) czy Nicei $(325 \text { r. })^{24}$.

\footnotetext{
${ }^{21}$ F. X. Wernz, P. Vidal, Ius canonicum ad Codicis normam exactum, T. I. Normae Generales, Romae 1938, s. 72-73.

${ }^{22}$ Dokumenty synodów od 50 do 381 roku, red. A. Baron, H. Pietras, Kraków 2006, s. $62-68$.

${ }^{23}$ A. Dembiński, Kościół i prawo rzymskie, s. 39.

${ }^{24}$ Postanowienia synodu w Elwirze (ok. 306 r), który podjął wiele spraw dotyczących dyscypliny kościelnej, noszą również nazwę kanonów. Były to zatem reguły dyscyplinarne, wskazując wyraźnie, co należy uczynić. Dokumenty synodów od 50 do 381 roku, s. 49-61.
} 
Określenie kanon wykorzystywane przez chrześcijan posiadało znaczenie prawne u Greków oraz Rzymian. Nie było wymysłem chrześcijan. Stało się jednak dla nich synonimem prawa i od VIII w. używane było na określenie prawa wspólnoty chrześcijańskiej jako prawo kanoniczne ${ }^{25}$. Dlaczego jednak chrześcijanie posłużyli się określeniem kanon, gdy w świecie, w którym przyszło im wzrastać powszechnym określeniem prawnych reguł postępowania były leges? Można to wytłumaczyć tym, że chrześcijanie chcieli pokazać, iż mają swoje własne prawo przez siebie stanowione, niezależne od jakiejkolwiek władzy zewnętrznej, którego są zobowiązani przestrzegać. Odpowiedź jest poprawna, ale niewystarczająca i niewiele mówiąca o świadomości własnego prawa. Zastosowanie terminu kanon na określenie własnego prawa wykracza poza znaczenie jakie nadaje mu sformułowanie nomos czy lex. Jest od nich szersze, gdyż odnosi się do zobowiązującej rzeczywistości wykraczającej poza ludzkie stanowienia. Treścią kanonu, jak to mamy w Liście do Galatów, jest fakt śmierci Jezusa, która jest podstawą chrześcijańskiej egzystencji. Kanon określa to, co najważniejsze. Wprowadza kryterium wartościowania i oceny przynależności do ludu Bożego oraz rozsądzania spraw wynikających z przyjęcia wiary i jej życiowych konsekwencji. Dlatego też kanon łączył w sobie określenie tego, co istotne dla wiary (canones fidei), dla życia moralnego (canones morum) i kościelnej dyscypliny (canones disciplinae). Kanon to całość prawd wiary oraz reguły zachowań. Używanie terminu kanon w odniesieniu do zachowań dyscyplinarnych wskazywało na ich odniesienie do prawd wiary, których nieprzestrzeganie skutkowało wyłączeniem z Kościoła.

Szersze niż lex znaczenie terminu kanon w odniesieniu do reguł dyscyplinarnych było tłumaczone jako reguła, z biegiem czasu norma, prawna. Zastosowanie terminu kanon do określenia prawa Kościoła mianem kanoniczne wskazywało również na jego specyfikę, która odnosiła to prawo w sposób koniecznościowy do wyznania wiary. Leges wskazywały na nakaz władcy, który nadaje im moc prawną

\footnotetext{
${ }^{25}$ A. Vermeersch, J. Creusen, Epitome Iuris Canonici, Mechliniae - Romae 1927, s. 1 .
} 
skutkującą obowiązkiem ich przestrzegania. Element obiektywny decydował o ich obowiązywaniu. Kanon wyznaczający to, co właściwe, reguła, zasada, według których należy postępować uwzględniał również subiektywne okoliczności, a jego treść miała swoje podstawy w nauczaniu wiary. $Z$ tego powodu nie zawsze rysowała się wyraźna różnica formalna czy nawet rzeczowa pomiędzy kanonami określającymi sposoby sprawowania liturgii, określającymi kanoniczne księgi natchnione, wykładającymi prawdy wiary czy wyznaczającymi dyscyplinę kościelną. Dla nich wszystkich nie wola prawodawcy, lecz wiara jako miara rzeczy, decydowała o ich zobowiązującym charakterze ${ }^{26}$.

Zestawiając obok siebie określenie prawa kanonicznego i prawa kościelnego, warto wskazać na kilka konkluzji.

1. Prawo kościelne w znaczeniu, w jakim zostało użyte po raz pierwszy, posiadało znaczenie obiektywnej normy, do której należało się stosować. W okresie, w którym zaczęło być używane, był już znany i powszechnie stosowany termin kanon. Papież Syrycjusz nie odwołuje się do kanonu, lecz zestawia prawa kościelne z prawami publicznymi. Można sugerować, że w ten sposób podkreślił ważność jednych i drugich dla rozwiązania konkretnego przypadku, jak również uznał charakter prawny prawa kościelnego na równi z prawem społeczności świeckiej.

2. Termin prawo kościelne nie miał większego znaczenia niż to, które odnosiło się do wskazania, że ze względu na swoje pochodzenie (ratione originis) jest prawem ogłaszanym przez Kościół jako prawo Boże lub przez niego stanowione jako prawo ludzkie. Było prawem kościelnym również ze względu na swój przedmiot i podmiot (ratione materiae), gdyż dotyczyło kwestii i osób należących do wspólnoty kościelnej.

3. Termin prawo kanoniczne, inaczej niż prawo kościelne, nie wskazywał jedynie na prawo społeczności kościelnej, ale odzwierciedlał również charakter tego prawa, uwidoczniony

\footnotetext{
${ }^{26}$ R. Sobański, Nauki podstawowe prawa kanonicznego. T. 1. Teoria prawa kanonicznego, s. 112-113.
} 
w znaczeniu pojęcia kanon oraz podkreślał gatunkową różnicę pomiędzy prawem kanonicznym i świeckim ${ }^{27}$.

4. Z biegiem czasu oba pojęcia utraciły swoje pierwotne znaczenia i zaczęły oznaczać prawo Kościoła w znaczeniu całości norm prawnych regulujących dyscyplinę kościelnej społeczności. Duży wpływ na takie rozumienie prawa w Kościele miała reforma gregoriańska i centralizacja powszechnej władzy ustawodawczej w osobie papieża. Nazwy prawo kanoniczne i kościelne służyły głównie do obrony prawa własnego Kościoła wobec tez Marsyliusza z Padwy (prawo jest wynikiem działalności państwowej), czy następnie Samuela Puffendorfa (Kościół jako organizacja stowarzyszeniowa nie posiada władzy ustawodawczej i możliwości stanowienia prawa). Nazwy te stosowane były zamiennie ${ }^{28}$, aczkolwiek termin prawo kanoniczne przeważał w użyciu, czego weryfikacją jest jego zastosowanie w kodeksach prawa Kościoła ${ }^{29}$.

5. Oba terminy, aczkolwiek wyjaśniane historycznie przez odwołanie się do ich pierwotnego znaczenia, nie miały przed długie wieki żadnego odniesienia do głębszych rozważań dotyczących natury prawa Kościoła. Podawane definicje prawa wspólnoty wierzących rozpoczynały się najczęściej od stwierdzenia, że jest to zespół ustaw, wedle których rządzi się Kościół. Dopiero badania nad naturą prawa Kościelnego wzbudzone na początku lat 50-tych ubiegłego stulecia przyczyniły się do głębszego spojrzenia na oba terminy, jednak nie tyle w perspektywie ich historycznego znaczenia, co raczej aktualnego stanu wiedzy o naturze prawa Kościoła.

\footnotetext{
${ }^{27}$ TAMŻE, s. 109.

${ }^{28} \mathrm{~W}$ komentarzach do pierwszego kodeksu powyżej cytowanych częściej jednak używa się sformułowania ius ecclesiasticum niż ius canonicum.

${ }^{29} \mathrm{~W}$ Kodeksie prawa kanonicznego z 1917 r. znajdujemy zastosowanie obu terminów bez jakiejkolwiek różnicy między nimi: prawo kanoniczne (kann. 117, 147, 166), prawo kościelne (kann. 27, 727, 1043). Ta sama praktyka występuje w obowiązującym kodeksie. Przykładowo ius canonicum zostało użyte w kann 22, 26, 98, 113, ...., a ius ecclesiasticum w kann. 1078, 1079, 1156.
} 


\section{Prawo Kościoła}

Podczas prezentacji Kodeksu prawa kanonicznego już po jego promulgacji Jan Paweł II wyjaśnił znaczenie prawa w Kościele ${ }^{30}$. Nie używa sformułowania prawo kanoniczne czy prawo kościelne, lecz mówi o prawie w Kościele. Następnie wyjaśnia, dlaczego to prawo jest w Kościele i czemu ono służy. Dzięki temu stwierdzenie o istnieniu prawa w Kościele nabiera ono pełniejszego sensu, gdyż samo w sobie nie oznacza jeszcze, że jest to prawo Kościoła, lecz jedynie, że w Kościele jest jakieś prawo. Wskazując na biblijną historię Objawienia i współpracę Boga z człowiekiem, wskazuje na prawo, które jest wyrazem tego zbawczego związku. Dlatego stosuje określenie, jak najbardziej adekwatne dla jego odzwierciedlenia, posługując się sformułowaniem ius sacrum. Następnie papież mówiąc o prawie w Kościele wskazuje na dwie rzeczywistości ze sobą zespolone. Jest to prawo Kościoła w jego powszechności oraz prawo Kościoła w ujęciu pozytywnym. W pierwszym znaczeniu prawo w Kościele jest całością relacji pomiędzy wiernymi o charakterze zobowiązującym, zdeterminowanych przez charyzmaty, sakramenty, zadania, które stwarzają odpowiednie reguły zachowania z nich wynikające. W drugim znaczeniu, zespolonym z pierwszym i od niego pochodnym, prawo w Kościele jest całością norm pozytywnie stanowionych przez odpowiednią władzę, które regulują wzajemne relacje międzyosobowe w życiu wspólnoty kościelnej tworząc w ten sposób instytucje określające kościelny porządek prawny ${ }^{31}$.

Mówiąc o prawie w Kościele w znaczeniu jego powszechności, papież nie posługuje się terminami prawo kanoniczne czy kościelne. Chodzi bowiem niezależnie od nazwy o prawo Kościoła, które nie jest w Kościele, jak mówi papież, ciałem obcym, ani jego nieużyteczną nadbudową czy pozostałością domniemanych roszczeń doczesnych.

\footnotetext{
${ }^{30}$ Joannes Paulus II, Ho desiderato [3.02.1983], Acta Apostolicae Sedis 75/1 (1983), s. $455-463$.

${ }^{31}$ G. Ghirlanda, Diritto Canonico, w: Nuovo Dizionario di Diritto Canonico, a cura di C. Corral Salvador, V. De Paolis, G. Ghirlanda, Cinisello Balsamo 1993, s. $350-351$.
} 
Jest prawem, które leży w naturze Kościoła. I to jest moim zdaniem najwłaściwszy sposób określania prawa w Kościele. To nie tyle prawo w Kościele, ale prawo Kościoła, rozumiejąc przez to, że jest nim nie w znaczeniu pochodzącego od kościelnych autorytetów (prawo w ujęciu pozytywnym), lecz istniejącego wraz z Kościołem jako element jego natury. Prawo Kościoła jest jego prawnym wymiarem, prawnym wymiarem wiary. Takie rozumienie prawa powinno przyświecać każdemu kościelnemu ustawodawcy niezależnie od tego, czy wyraża normy regulujące kościelną dyscyplinę w formie kodeksowej (kanonicznej) czy pozakodeksowej (kościelnej).

Wprowadzanie, moim zdaniem, na siłę, rozróżnienia na prawo kanoniczne i kościelne mija się z sensem. Jedno i drugie określenie ma swoją historię i oba są powszechnie przyjmowane na określenie kościelnego zjawiska prawnego. Tradycja kanonistyczna nie jest jedynie wspomnieniem przeszłości, ale stanowi ważny element zrozumienia teraźniejszości i świadczy o historyczności doświadczenia prawnego w Kościele.

Prawo Kościoła jest prawem kanonicznym. Wyrażano je w formie pisanej za pomocą określenia kanon, które miało swe głębokie znaczenie wykraczające poza rzymskie ustawy. Poza tym pozwalało na odróżnienia prawa kościelnej wspólnoty od prawa państwowego i wskazywało na jego niezależność oraz, we właściwym tego słowa znaczeniu, autonomię Kościoła. Kanon nie nadawał znaczenia prawu Kościoła, lecz był właściwą formą pozwalająca na jego wyrażenie. Nie kanon decydował o prawie, lecz prawo o tym, że było zawarte w kanonach. A było zawarte w kanonach dlatego, że było prawem Kościoła. Nie widzę podstaw, by czynić różnicę pomiędzy prawem w kanonach i poza nimi. Jest to zawsze prawo Kościoła. Można postawić pytanie, czy termin prawo kanoniczne przestałby być właściwy, gdyby w Kościele zrezygnowano z kodeksu, w którym zawarte są kanony? Nie widzę sensu nadawania nowego znaczenia utartemu i popartemu tradycją terminowi. Próby takie wymagałyby uzasadnienia samego procesu myślowego, a nie tylko wskazania desygnatu odpowiadającego z góry przyjętej tezie. 
Uważam, że pod wpływem II Soboru Watykańskiego, a także rozwijającego się morfologicznego podejścia do zagadnień prawa kanonicznego, wskazującego na jego związek z naturą Kościoła, sformułowanie prawo kościelne lepiej ukazuje związek pomiędzy prawem i Kościołem. Prawo kościelne nie jest prawem poza kanonami. Gdyby je tak ujmować to, czy należałoby je traktować jako inne prawo niż obecne w kanonach? Prawo Kościoła w jego globalności znajduje swój wyraz niezależnie od nazw narzędzi, dzięki którym staje się powszechnie znane. Przy dzisiejszej świadomości natury prawa Kościoła rozróżnienie na leges i canones nie znajduje aż tak wielkich racji, by właściwe posługiwanie się nimi decydowało o specyfice treści w nich zawartych. Przy wykorzystaniu osiągnięć nauk prawnych samo określenie canon traci dziś swoje specyficzne znaczenie i jest raczej przedmiotem naukowych nieporozumień, zwłaszcza wtedy, gdy używamy sformułowań takich jak norma, przepis jako raz równoznaczne, a drugi przeciwstawne określeniu kanonu. Dodatkowo nie przyczyniają się do jasności terminologicznej i znaczeniowej połączenia typu norma kanoniczna czy przepis kanoniczny, zwłaszcza wtedy, gdy terminy są ze sobą utożsamiane.

\section{Canon law or Church law?}

In the Polish science of canon law there is a tendency to distinguish canon law from Church law. The first one concerns the law included in the Code of canon law and the latter the other acts of established law. The author of the study analyses the historical meaning of the terms canon law and Church law as equivalent terms for describing the same experience of law in the Church community. However, he believes that in the current state of knowledge the phrasing Church law better expresses the relationship between law and the nature of Church than the traditional phrasing canon law.

SŁOWA KLUCzOWE: prawo; prawo kanoniczne; prawo kościelne; podobieństwo; różnica

KEYwORDs: law; canon law; church law; similarity; difference 


\section{Nota o Autorze:}

O. DR HAB. Tomasz GaŁkowski C.P., PROF. UKSW - profesor nadzwyczajny na Wydziale Prawa Kanonicznego UKSW w Warszawie, kierownik zakładu Teorii Prawa Kanonicznego w katedrze Teorii i Norm Ogólnych Prawa Kanonicznego. 